With 3 plates

Printed in Great Britain

\title{
Morphological Changes of Vibrio cholerae Organisms in Glucose Saline
}

\author{
By J. DAS* AND S. N. CHATTERJEE \\ Department of Biophysics, School of Tropical Medicine, Calcutta-12, India
}

(Accepted for publication 9 August 1968)

\section{SUMMARY}

Morphological changes in Vibrio cholerae harvested from $\mathrm{I} 8 \mathrm{hr}$ growth on nutrient agar surface and incubated in glucose saline at $37^{\circ}$ have been studied by electron microscopy using metal shadowing, uranyl staining and thin sectioning techniques. Within the $6 \mathrm{hr}$ incubation period, a vacuolar region has been found to separate the cell wall from the protoplasmic body presumably at one polar end. Subsequently such separation has been found all round the periphery of the protoplasmic body, which assumes a round form of average dimension $0.4 \pm 0.05 \mu$. Within the $24 \mathrm{hr}$ incubation period, majority of the cells (60 to $70 \%$ ) are rounded and of these a significant fraction (15 to $20 \%$ ) contained bodies limited by one single membrane. It is suggested that these bodies represent the protoplasts of $V$. cholerae.

\section{INTRODUCTION}

Gallut (1954) reported that a toxic substance is produced when the Vibrio cholerae organisms are incubated in glucose saline. He also mentioned that the toxin is produced by the solubilization of the cell wall and that the resultant bodies are not agglutinated by the homologous anti-O-immune sera (Gallut, 1965). No systematic study has yet been made by electron microscopy on the morphological changes these vibrios undergo during incubation in glucose saline. In our earlier studies (Chatterjee \& Das, 1966, 1967) it was reported that during the early period of incubation (within $1.5 \mathrm{hr}$ ), V. cholerae organisms excrete small particles which are bounded by the cell-wall material. The present paper deals with the morphological changes of the vibrios at subsequent periods of incubation in glucose saline as studied by the thin sectioning, metal shadowing and uranyl staining techniques.

\section{METHODS}

Bacterial strains and condition of growth. Two strains of Vibrio cholerae, INABA C84 (obtained through the courtesy of Dr K. N. Neogy, Department of Bacteriology of this Institution) and OGAWA I 54 (obtained through the courtesy of Dr S. Mukherjee, Indian Institute of Experimental Medicine, Calcutta) were used throughout this investigation. Organisms were grown either in nutrient broth or in $I \%(w / v)$ peptone water $(\mathrm{pH} 8.0)$ for about $\mathrm{I} 8 \mathrm{hr}$ at $37^{\circ} .0 .1 \mathrm{ml}$. of this culture was inoculated and spread over the surface of a nutrient agar plate and incubated at $37^{\circ}$ for 16 to $18 \mathrm{hr}$, so as to obtain a uniform surface growth.

* Present address: Department of Microbiology, Baylor University College of Medicine, Houston, Texas 77025, U.S.A. 
Incubation in glucose saline. Vibrios from the $\mathrm{I} 8 \mathrm{hr}$ growth on the nutrient agar surface were suspended in $0.85 \%$ saline and washed twice by centrifugation. The washed vibrios were then suspended in suitable volumes of glucose saline $(\mathrm{NaCl} 0.85 \mathrm{~g}$., glucose 0.5 g., distilled water $100 \mathrm{ml}$.) (Bernard \& Gallut, I943; Gallut, I954) distributed in Erlenmeyer flasks ( $100 \mathrm{ml}$. capacity) in volumes of $20 \mathrm{ml}$., the initial optical density of the suspension thus being adjusted in the range 0.8 to $\mathrm{I} \cdot 0$. The suspension was then incubated at $37^{\circ}$ for a maximum period of $24 \mathrm{hr}$.

Fixation of incubated cells. Vibrio cholerae organisms were harvested from the glucose saline at different periods of incubation by centrifugation and fixed immediately by resuspending in Ringer solution containing either $\mathrm{I} \%(\mathrm{w} / \mathrm{v})$ osmium tetroxide or $4 \%(w / v)$ formaldehyde. Fixation was carried out at o to 4 for 4 to $24 \mathrm{hr}$. In some cases fixation was carried out by dissolving the osmium tetroxide or formaldehyde in the glucose saline solution to the desired concentration and keeping the whole at 0 to $4^{\circ}$.

Metal shadowing. For metal shadowing, a small drop of the suspension after fixation was deposited on carbon collodion-coated copper wire mesh and the excess liquid was withdrawn a few seconds later. The preparation was then washed thoroughly by rinsing in distilled water, dried and shadowed obliquely with chromium.

Uranyl staining. Vibrio cholerae organisms deposited on the carbon collodion substrate after the desired period of incubation in glucose saline solution and subsequent fixation, were stained positively by floating the grids, film side down, on the surface of a $\mathrm{I} \%(\mathrm{w} / \mathrm{v})$ uranyl acetate solution in distilled water for about $\mathrm{I} \mathrm{hr}$. The grids were then washed thoroughly in distilled water and dried.

Thin sectioning. The cells after incubation in glucose saline solution for the desired period were harvested by centrifugation and the pellet was fixed in $\mathrm{I} \%(\mathrm{w} / \mathrm{v})$ solution of osmium tetroxide in Kellenberger buffer ( $\mathrm{pH} 6 \cdot \mathrm{I}$ ) for $\mathrm{I} 6$ to $20 \mathrm{hr}$ at room temperature (Kellenberger, Ryter \& Sechand, 1958). The fixed cells were washed in $0.5 \%$ solution of uranyl acetate in the said buffer for about $2 \mathrm{hr}$. The washed cells were placed between layers of agar, dehydrated in graded ethanol and embedded in a methacrylate mixture (methyl+butyl, 2+3) or in Epon (Luft, 196I). Methacrylate mixture was prepolymerized (Borysko \& Sapranauskas, 1954) to reduce the polymerization damage and the corresponding sections after being stained were overlaid in most cases with a thin film of carbon (Watson, 1957) to reduce the sublimation artifact. Thin sections were cut with glass knives on a Porter Blum ultramicrotome. Sections were stained with uranyl acetate and/or lead citrate or potassium permanganate (Lawn, 1960). Vibrios harvested from $24 \mathrm{hr}$ growth on nutrient agar were fixed, embedded and sectioned under identical conditions as control.

Electron microscope. All electron micrographs were taken by a Hitachi HS-6 electron microscope at instrumental magnification ranging from $\times 6000$ to 15,000 . Measurements were made from the enlarged prints by a micrometer eyepiece (accuracy $O \cdot I \mathrm{~mm}$ ).

\section{RESULTS}

During the incubation of Vibrio cholerae organisms in glucose saline at $37^{\circ}$ interesting changes in cellular morphology were noted. Within the first $\mathrm{I}$ to $\mathrm{I} \cdot 5 \mathrm{hr}$ incubation, the vibrios were found to release in the environmental medium cell-wall materials in the form of approximately round particles. The dimension of these particles varied between 400 and $\mathrm{I} 100 \AA$ in most cases as described in detail in our earlier publications 
(Chatterjee \& Das, 1966, 1967). At this period all the vibrios maintained their rod-like structure as in the native stage (Pl. I, fig. I). Also thin sectioning of the vibrios harvested at this stage of incubation in glucose saline revealed no significant difference in the ultrastructure of their protoplasmic constituents as compared to what was found in the vibrios grown on agar surface (P1. 2, fig. 5).

At subsequent stages of incubation the normal relative disposition of the cell wall and plasma membrane was changed gradually with time in the majority of the vibrios. Organisms harvested from 2 to $6 \mathrm{hr}$ incubation in glucose saline revealed that the cell wall was separated from the protoplasmic mass by a wide vacuolar region (P1. 2, fig. 6) at one end only. A similar picture was also found in metal-shadowed preparations (P1. I, fig. 2) where due to the limitation of the technique the presence of the vacuolar region separating the extended cell wall and the protoplasm was not evident. Plate $\mathrm{I}$, fig. 2, illustrates that the separation has taken place at one polar end. The cell wall, presumably, got weakened at this stage and the protoplasmic mass began to assume a spherical form out of the native rod-shaped structure (Pl. I, fig. 3). It appeared from P1. I, fig. 3, that more than one rounded protoplasmic bodies would form per single bacterium.

In the 6 to $24 \mathrm{hr}$ incubation period, majority of the vibrios assumed rounded forms having a much denser round protoplasmic core covered by a larger envelope of weakened or degraded cell wall and presenting the appearance of a poached egg (Pl. I, fig. 4a). Thin section at this stage revealed that the separation between the cell wall and the protoplast was complete practically all over the latter's periphery (Pl. 2, fig. 8). The structure of the cell wall became considerably degraded and breaks appeared in the cell-wall structure (P1. 3, fig. 9). At this stage, round protoplasmic bodies were found in the process of getting rid of the cell-wall envelope (Pl. 2, fig. 7). Envelopes discarded in this process apparently did not contain any protoplasmic body (Pl. 3, fig. 9, I I). In Pl. I, fig. $4 b$, many of the round protoplasmic bodies apparently did not retain any remnant of the envelope. Some of them presented a doublet structure and one appeared to be in the process of being pinched off a rod-shaped body (arrow). At higher magnification, thin section revealed the presence of one limiting membrane (thickness 70 to $90 \AA$ ) around many of these protoplasmic bodies (Pl. 3, fig. I0). These bodies contained a nuclear vacuole surrounded by a denser cytoplasmic area and have a diameter between 0.3 and $0.6 \mu$ with an average of $0.4 \pm 0.05 \mu$.

By counting the electron micrographs of the thin sections as well as the shadow-cast preparations of the cells after the $24 \mathrm{hr}$ incubation period, a rough estimate of the percentage of the different types of bodies formed was made. It was found that over 60 to $70 \%$ of the Vibrio cholerae organisms were converted into round forms and of these a significant fraction ( 15 to $20 \%$ ) contained bodies limited by one single membrane. The rest of the bodies still retained the cell-wall layer separated from the protoplast by a wide vacuolar area.

\section{DISCUSSION}

The different stages of the formation of spherical bodies from Vibrio cholerae organisms incubated in glucose saline, as obtained in the present investigation, are of interest. Evidences obtained suggest that each rod-shaped protoplasmic mass of the $V$. cholerae organism transforms into more than one spherical bodies whose diameter is on the average not greater than the width of the intact cells. Individual 
spherical bodies are separated from the parent protoplasmic mass apparently by a pinching off process. These observations are not in accord with the mode of formation of spheroplasts from Escherichia coli and Proteus vulgaris grown in presence of penicillin (McQuillen, 1960; Lederberg, 1956) or of E. coli deprived of diaminopimellic acid (McQuillen, 1958). However, the formation of a large vacuolar region where the outer wall and the inner plasma membrane of the spherical bodies have separated, as found in the present investigation, has been commonly encountered in spheroplasts of Gram-negative bacteria induced by the growth in the presence of penicillin or glycine or by the deprivation of diaminopimellic acid (Thorsson \& Weibull, 1958).

Action of different physico-chemical agents on a varietyof bacteria and the consequent changes induced in them have been investigated by many authors and reviewed recently by Stolp \& Starr (1965). Antibiotics such as penicillin, enzymes such as lysozyme and amino acids such as glycine have been observed to lyse bacteria unless otherwise protected by an osmotically stable system. Under the action of these agents many bacteria in an osmotically protected system have been observed to transform into spherical forms (Brenner et al. 1958; Hines, Freeman \& Pearson, 1964; McQuillen, 1960; Mitchell \& Moyle, I956; Salton, 1961 ; Weibull, 1953) which are usually termed protoplasts or spheroplasts in accordance with the complete absence or not of any cell-wall material covering such spherical bodies. Jeynes (196I) reported that the Vibrio cholerae organisms grown in the presence of glycine transform into true protoplasts by the complete loss of outer wall component. According to Gallut \& Giuntine (1963) if the $V$. cholerae organisms are incubated in glucose saline at $37^{\circ}$ true protoplasts are formed by the solubilization of the cell wall. However, thin sections of the resulting bodies were not examined in any of the above investigations on $V$. cholerae. The problem of deciding about the presence or absence of the cell wall in Gramnegative bacteria in the osmotically sensitive form was discussed by Brenner et al. (1958) and the need for the adoption of thin sectioning technique in such cases was emphasized.

The action of glucose saline on the Gram-positive or Gram-negative bacteria has not been investigated so far. Considerable evidence has, however, been obtained in the present investigation to conclude that Vibrio cholerae organisms are mostly converted into spherical forms by incubation in glucose saline. Uranyl stained as well as shadowed preparations of unsectioned cells have indicated that the spherical forms shed the considerably weakened and degraded cell wall. Thin sections have revealed the presence of wide vacuolar region between the spherical protoplasmic mass and the cell wall and also breaks or discontinuities in the cell-wall structure. These observations suggest the possibility of the complete separation of the protoplasmic mass from the degraded cell-wall layer. At higher magnification a membrane of thickness between 70 and $90 \AA$ has been found to limit many of these round protoplasmic bodies. No other membrane beneath this has been evident in the electron micrographs. It is unlikely that this membrane represents the cell wall since wide separation between the protoplast and the cell wall has been noticed even at a shorter period of incubation of the vibrios in glucose saline. Hofschneider (1960) observed the presence of a single membrane limiting a number of $E$. coli treated with EDTA and lysozyme and suggested that it was the cytoplasmic membrane. Birdsell \& Cota-Robles (1967) confirmed these findings. Costerton et al. (1967) also recorded the presence of a single membrane 
limiting a marine pseudomonad after treatment with EDTA and lysozyme. It is thus suggested that the single membrane found, in this investigation, to limit many of the round bodies represents the plasma membrane and that the corresponding bodies are the protoplasts of $V$. cholerae.

This work forms part of a thesis submitted by J. Das and accepted for the D.Phil. degree by the University of Calcutta.

The authors are indebted to Dr J. B. Chatterjea, Director, School of Tropical Medicine, Calcutta, for his kind interest in the work. This investigation was supported by a research grant from the Indian Council of Medical Research, Government of India.

\section{REFERENCES}

Bernard, P. N. \& Gallut, J. (1943). Sur une mode de préparation de la toxine cholerique. $C$. $r$. Séanc. Soc. Biol. r37, Io.

Birdsell, D. C. \& Cota-Robles, E. H. (1967). Production and ultrastruture of lysozyme and ethylenediaminetetraacetate-lysozyme spheroplasts of Escherichia coli. J. Bact. 93, 427.

Borysko, E. \& Sapranauskas, P. (1954). A new technique for comparative phase contrast and electron microscope studies of cells grown in tissue culture with an evaluation of the technique by means of time lapse cinemicrographs. Bull. Johns Hopkins Hosp. 95, 68.

Brenner, S., Dark, F. A., Gerhardt, P., Jeyens, M. H., Kandler, O., Kellenberger, E., Klieneberger-Nobel, E., McQuillen, K., Rubio-Huertos, M., Salton, M. R. J., Strange, R. E., Tомсsiк, J. \& Weirull, C. (1958). Bacterial protoplasts. Nature, Lond. 181, 1713.

ChatTerJeE, S. N. \& DAS, J. (1966). Secretory activity of Vibrio cholerae as evidenced by electron microscopy. In Electron Microscopy. Ed. by R. Uyeda, Vol. 2, p. 259. Tokyo: Maruzen Co. Ltd.

Chatterjee, S. N. \& Das, J. (1967). Electron microscopic observations on the excretion of cellwall material by Vibrio cholerae. J. gen. Microbiol. 49, I.

Costerton, J. W., Forsberg, C., Matula, T. I., Buckmire, F. L. A. \& Macleod, R. A. (1967). Nutrition and metabolism of marine bacteria. J. Bact. 94, 1764.

Gallut, J. (1954). Contribution à l'étude de la toxine cholerique: variation du pouvoir toxique de Vibrio cholerae (Ogawa) en cours de la maladie. Annls Inst. Pasteur, Paris 86, 561.

Gallut, J. (1965). Antigenic structure of vibrios. Proc. Cholera Res. Symp. Honolulu, p. 235.

Gallut, J. \& GiUNTINE, J. (1963). Étude de Vibrio cholerae au microscope électronique et relation entre l'aspect morphologique et l'agglutination 'O'. Bull. Wld Hlth Org. 29, 767.

Hines, W. D., Freeman, B. A. \& Pearson, G. R. (1964). Production and characterization of Brucella spheroplasts. J. Bact. 87, 438.

HofschNeIDER, P. H. (1960). Zur Wandstruktur von Escherichia coli B Sphaeroplasten. Proc. European Regional Conf. Electron Microscopy, Delft. Vol. 2, p. 1028.

JEYNES, M. H. (1961). The growth and division of bacterial protoplasts. Exp. Cell Res. 24, 255.

Kellenberger, E. \& RYTer, A. (1964). In Modern Developments in Electron Microscopy. Ed. by B. M. Siegel, p. 335. New York and London: Academic Press.

Kellengerger, E., RYTer, A. \& Sechand, J. (1958). Electronmicroscopic study of DNA plasma. J. biophys. biochem. Cytol. 4, 67I.

LAwN, A. M. (1960). The use of potassium permanganate as an electron dense stain for sections of tissue embedded in epoxy resin. J. biophys. biochem. Cytol. 7, 197.

LeDerberg, J. (1956). Bacterial protoplasts. Proc. natn. Acad. Sci. U.S.A. 42, 576.

LUFT, J. H. (196I). Improvements in epoxy resin embedding methods. J. biophys. biochem. Cytol. 9, 409.

MCQUILLEN, K. (1958). Lysis resulting from metabolic disturbance. J. gen. Microbiol. 18, 498.

McQumlen, K. (1960). Bacterial protoplasts. In The Bacteria. Ed. by I. C. Gunsalus and R. Y. Stanier, p. 249. New York: Academic Press Inc.

Milloning, G. (1961). A modified procedure for lead staining of thin sections. J. biophys. biochem. Cytol. III, 736

MrTCHELL, P. \& MoYLe, J. (1956). Autolytic 'protoplast' release in Bacterium coli. Nature, Lond. 178, 993. 
Salton, M. R. J. (I96I). The anatomy of the bacterial surface. Bact. Rev. 25, 77.

StolP, H. \& StarR, M. P. (1965). Bacteriolysis. A. Rev. Microbiol. 19, 79.

Thorsson, K. C. \& Weibull, C. (1958). Studies on the structure of bacterial L forms, protoplasts and protoplast like bodies. J. Ultrastruct. Res. I, 412.

Watson, M. L. (1957). Reduction of heating artifacts in thin sections examined in electron microscope. J. biophys. biochem. Cytol. 3, 1017.

WeIBUll, C. (I953). The isolation of protoplasts from Bacillus megaterium by controlled treatment with lysozyme. J. Bact. 66, 688.

\section{EXPLANATION OF PLATES}

Plate I

Fig. I. Vibrio cholerae harvested from $18 \mathrm{hr}$ growth on nutrient agar surface. Metal shadowed. $\times 21,000$.

Fig. 2. $V$. cholerae organism harvested from 2 to $6 \mathrm{hr}$ incubation in glucose-saline. Metal shadowed. CW, cell wall. $\times 48,000$.

Fig. 3. Vibrios harvested from 2 to $6 \mathrm{hr}$ incubation period. Arrow indicates the formation of round protoplasmic body. Metal shadowed. $\times$ I3,000.

Fig. 4a. A round protoplasmic body covered by a larger envelope of the cell wall (CW). Metal shadowed. $\times 30,000$.

Fig. $4 b$. Round protoplasmic bodies obtained in the 6 to $24 \mathrm{hr}$ incubation period. DS, doublet structure. Arrow indicates the formation of a round body apparently by a pinching off process. Metal shadowed. $\times$ I8,000.

\section{Plate 2}

Fig. 5. Ultrathin section of $V$. cholerae harvested from $\mathrm{I} 8 \mathrm{hr}$ growth on nutrient agar surface. $\times 45,000$.

Fig. 6. Ultrathin section illustrating the presence of vacuolar region (VAC) separating the cell wall (CW) from the protoplasmic body. $\times 55,000$.

Fig. 7. Uranyl stained preparation of $V$. cholerae harvested from 6 to $24 \mathrm{hr}$ incubation in glucose saline. The protoplasmic body has become round with the cell wall (CW) still attached to it. Arrow indicates one such body which is apparently free of the cell wall material. $\times 16,800$.

Fig. 8. Ultrathin section of a vibrio harvested from 6 to $24 \mathrm{hr}$ incubation period shows the separation of the cell wall $(\mathrm{CW})$ from the protoplasmic body all round the latter's periphery. $\times 80,000$.

\section{Plate 3}

Fig. 9. Ultrathin section of vibrios harvested from 6 to $24 \mathrm{hr}$ incubation period shows the presence of a break (arrow) in the cell wall (CW) structure. The protoplasmic bodies B and C are apparently free of the cell wall. An apparently discarded cell wall material $(\mathrm{CW})$ can be seen in the same field. $\times 66,000$. Fig. 10. One single membrane (M) is seen to limit the round protoplasmic bodies obtained in the 6 to $24 \mathrm{hr}$ incubation period. $\times 100,000$.

Fig. II. Apparently discarded cell-wall material (CW) in thin section. $\times 60,000$. 
Journal of General Microbiology, Vol. 54, No. 3

Plate I
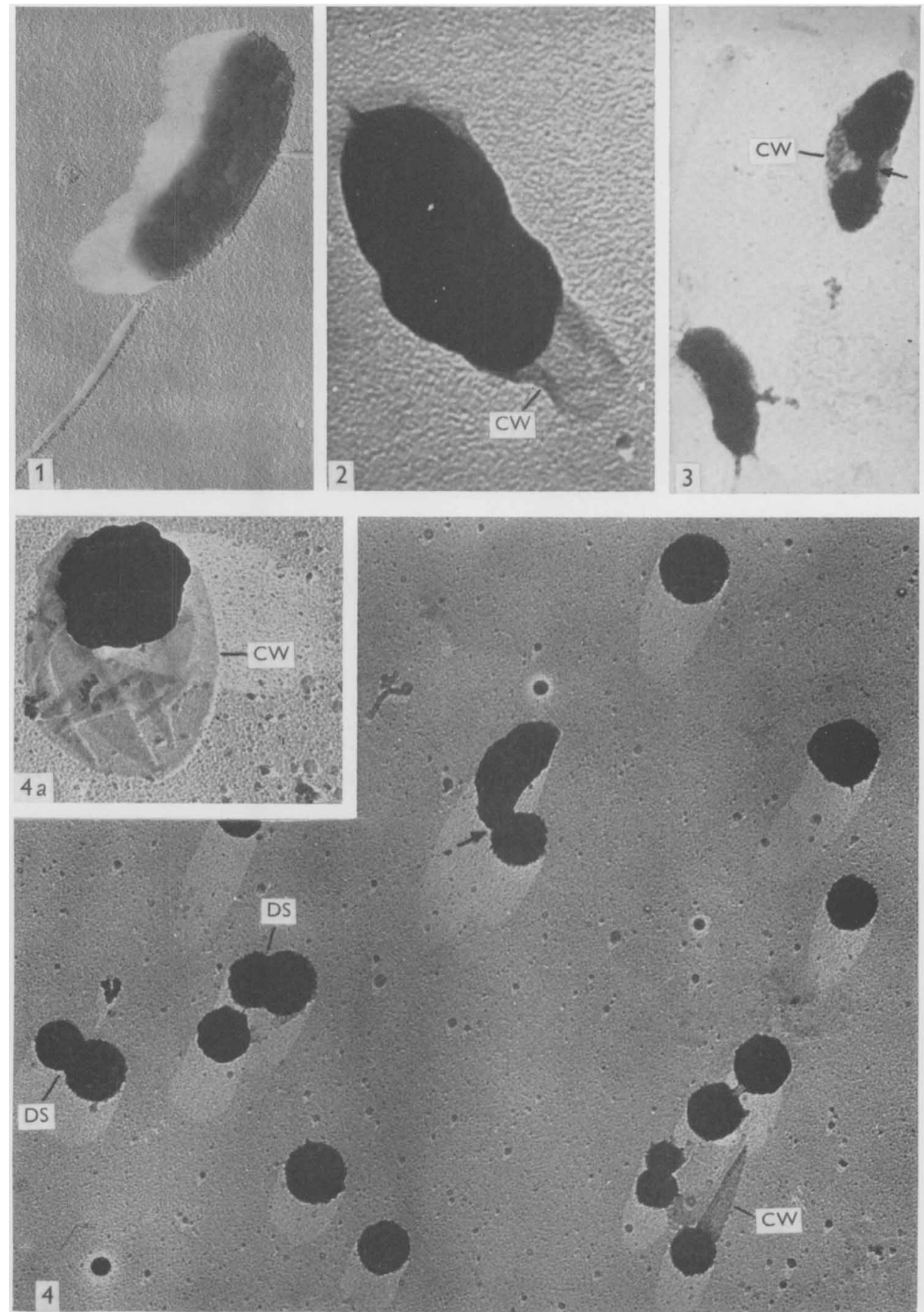
Journal of General Microbiology, Vol. 54, No. 3

Plate 2

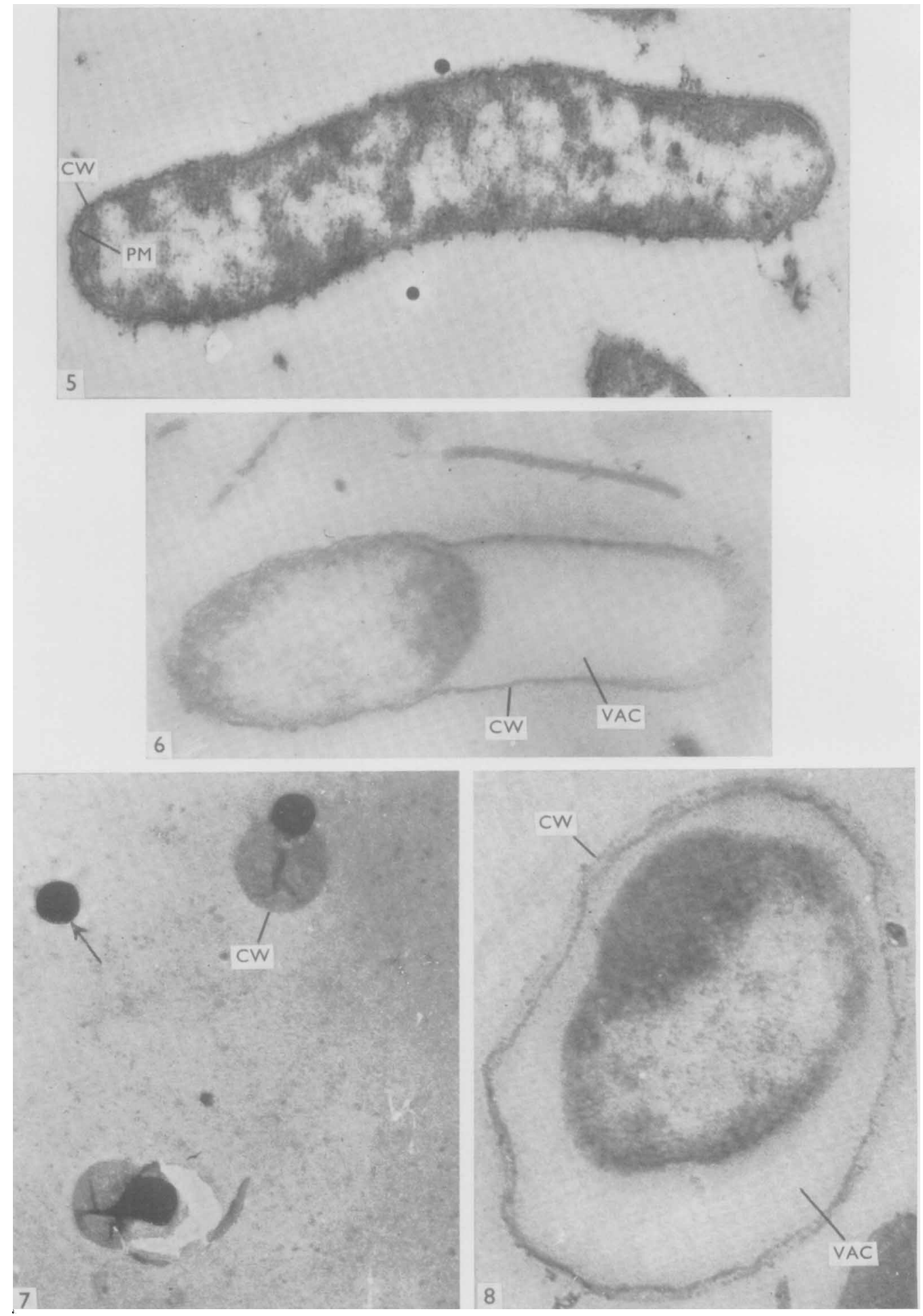

J. DAS AND S. N. CHATTERJEE 
Journal of General Microbiology, Vol. 54, No. 3

Plate 3
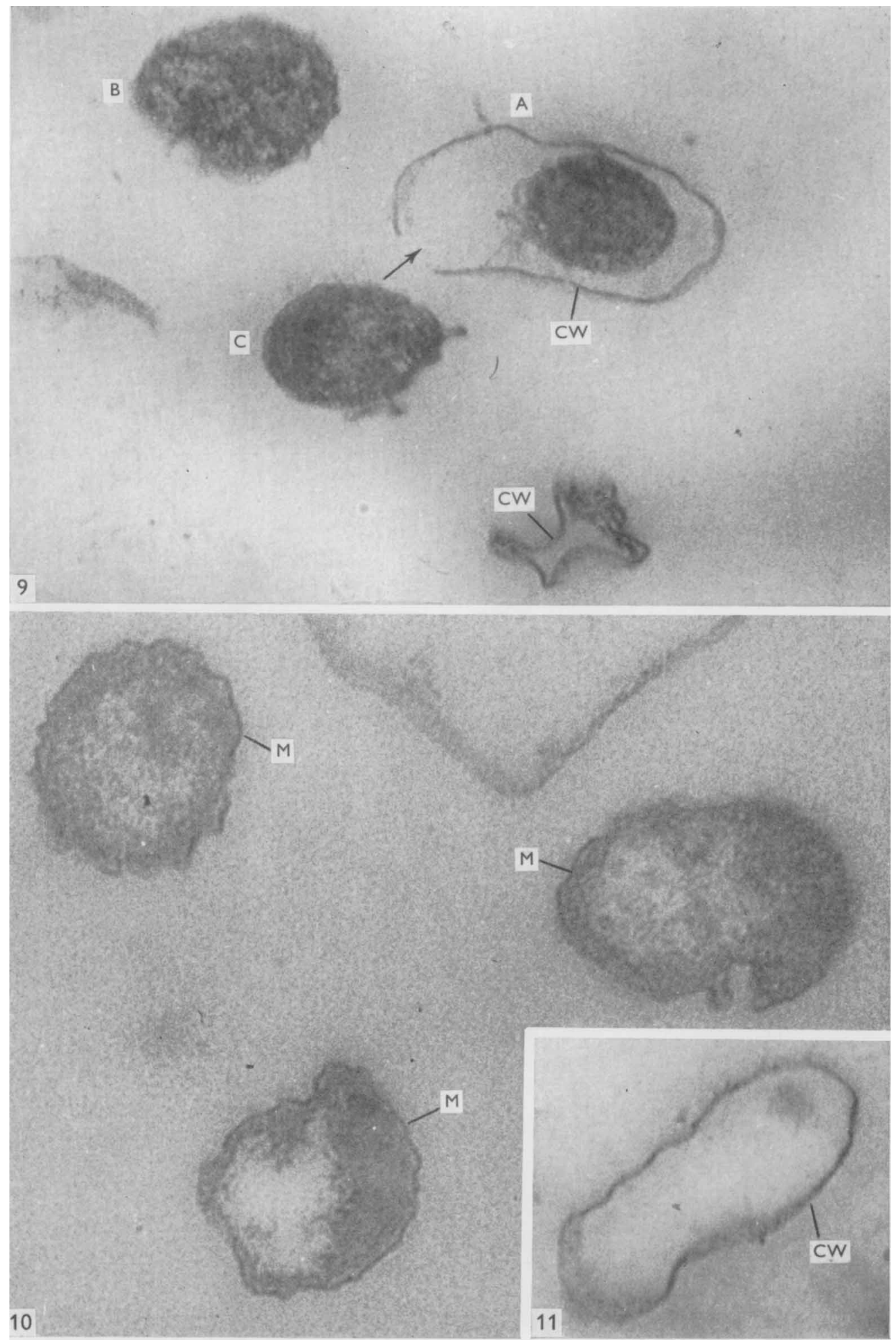

J. DAS AND S. N. CHATTERJEE 